\title{
Diversification of business and its implications for the welfare of traditional fishermen community in Uso Village, Batui District, Luwuk Banggai, Central Sulawesi Province
}

\author{
Diversifikasi usaha dan implikasinya terhadap kesejahteraan masyarakat nelayan \\ tradisional Desa Uso, Kecamatan Batui, Kabupaten Luwuk Banggai, \\ Provinsi Sulawesi Tengah
}

\author{
Srinurmahningsi ${ }^{1}$, Jardie A. Andaki ${ }^{2}$, and Adnan Wantasen ${ }^{2}$ \\ ${ }^{1}$ Program Studi Magister Ilmu Perairan, Program Pascasarjana Universitas Sam Ratulangi. Jl. Kampus Unsrat Kleak, \\ Manado 95115, Sulawesi Utara, Indonesia. \\ ${ }^{2}$ Fakultas Perikanan dan Ilmu Kelautan, Universitas Sam Ratulangi. Jl. Kampus Unsrat Bahu, Manado 95115 \\ Sulawesi Utara, Indonesia. \\ *E-mail: jardie.andaki.19@gmail.com
}

\begin{abstract}
This study aims to determine the business diversification selected by the fishing community in maintaining family life, to determine the difference in choice of business diversification as well as the implications on the fishing community of Uso Village, Batui District, Banggai Regency, Central Sulawesi Province. This study used a mixed method, which is a research approach that combines qualitative and quantitative research. Data used in this research is both descriptive and analytical. Comparative test was performed using Student's t-test. The results of this study concluded that 1) there is diversification outside the fishing effort by the fishermen of the village, such as working as construction workers, company workers, motorcycle taxi drivers, merchants and farming, 2) there is a significant difference between fishing effort and business diversifications in which the contsruction workers have lower income then the fishing efforts, while the income of business diversifications as company workers, motorcycle taxi drivers, and farmers are not significant, 3) diversification of fishing effort has a positive impact on the lives of fishermen to use their spare time not to fish due to weather factors, replace lost income because it does not go to the sea, and combines a variety of businesses in outside the fishing business potential in increasing the family income of fishermen in the village, and 4) cash-flow and financial analysis shows fishing effort is feasible, as well as diversification is feasible as the support of fishing effort.
\end{abstract}

Keywords: traditional fishery; business diversification, fishery community, Uso village; Luwuk Banggai.

Abstrak: Penelitian ini bertujuan untuk menentukan diversifikasi usaha yang dipilih oleh masyarakat nelayan dalam mempertahankan hidup keluarga, untuk menentukan perbedaan pilihan diversifikasi usaha dan implikasinya pada masyarakat nelayan Desa Uso, Kecamatan Batui, Kabupaten Banggai, Provinsi Sulawesi Tengah. Metode yang digunakan dalam penelitian ini, yaitu mixed-method. Analisis data menggunakan deskriptif analitik. Uji perbandingan menggunakan uji-t. Hasil penelitian dapat disimpulkan, 1) diversifikasi usaha, yang dilakukan selain usaha penangkapan ikan, yaitu bekerja sebagai buruh bangunan, buruh perusahaan, tukang ojek, pedagang dan bertani, 2) terdapat perbedaan nyata antara usaha penangkapan ikan dengan diversifikasi usaha di mana pendapatan sebagai buruh bangunan lebih rendah dari pendapatan nelayan. Sedangkan diversifikasi usaha sebagai buruh perusahaan, tukang ojek, dan bertani, tidak berbeda nyata, 3) diversifikasi usaha nelayan berimplikasi positif pada kehidupan nelayan dalam memanfaatkan waktu luang saat tidak melaut karena faktor cuaca, mengganti kehilangan pendapatan karena tidak melaut, dan mengkombinasikan berbagai usaha di luar usaha penangkapan ikan yang berpotensi pada peningkatan pendapatan keluarga nelayan, dan 4) Cash-flow dan analisis finansial menunjukkan bahwa usaha perikanan tangkap layak dilaksanakan, demikian pula diversifikasi usaha sebagai penunjang usaha nelayan.

Kata-kata kunci: nelayan; diversifikasi usaha; masyarakat nelayan; desa Uso; Luwuk Banggai.

\section{PENDAHULUAN}

Keberadaan nelayan tradisional di Desa Uso, Kecamatan Batui, Kabupaten Banggai, Sulawesi
Tengah, tidak lepas dari ketergantungan terhadap dinamika sumber daya alam dan lingkungannya. Namun, didapati budaya masyarakat pesisir Desa tersebut yang sesungguhnya tidak berjiwa bahari 
melainkan lebih berorientasi pada daratan. Hal ini dapat dilihat dari data penduduk di mana penduduk yang berprofesi sebagai nelayan hanya $4 \%$ dari total jumlah penduduk desa tersebut. Eksistensi masyarakat Desa Uso yang dikategorikan sebagai nelayan tidak murni sebagai nelayan karena mereka juga bekerja sebagai petani/peternak, tukang, buruh dan pengeksploitasi jasa lingkungan pesisir lainnya.

Menyadari akan hal ini, maka sepantasnya jika orientasi pembangunan masyarakat pesisir diarahkan pada upaya peningkatan kesejahteraan dengan memanfaatkan berbagai potensi sumber daya yang ada dalam bentuk diversifikasi usaha. Berdasarkan permasalahan ini, maka perlu dilakukan penelitian guna menganalisis dan mengupayakan diversifikasi usaha masyarakat nelayan tradisional Desa Uso demi meningkatkan kesejahteraan masyarakat pesisir/ nelayan atau rumah tangga nelayan.

Penelitian ini bertujuan untuk menentukan diversifikasi usaha yang dipilih oleh masyarakat nelayan guna mempertahankan hidup mereka dan keluarga, dan menentukan perbedaan pilihan diversifikasi usaha serta implikasinya pada masyarakat nelayan Desa Uso, Kecamatan Batui, Kabupaten Banggai, Sulawesi Tengah.

Kegiatan diversifikasi usaha yang dimaksudkan di dalam penelitian ini adalah kegiatan usaha yang dilakukan oleh nelayan di Desa Uso, yang bertujuan meningkatkan pendapatan. Penelitian ini dibatasi pada kegiatan usaha yang benar-benar dilakukan oleh nelayan sehari-hari tanpa ada kegiatan sisipan yang dilakukan karena suatu proyek pemerintah dan/atau swasta.

\section{MATERIAL DAN METODA}

Metode yang digunakan dalam penelitian ini, yaitu mixed-method, yaitu merupakan pendekatan penelitian yang mengkombinasikan antara penelitian kualitatif dan kuantitatif (Creswell, 2010). Kombinasi ini dilakukan untuk memperoleh data yang lebih komprehensif, valid, reliabel dan obyektif (Sugiyono, 2011).

\section{Teknik Pengumpulan Data}

Penelitian ini merupakan penelitian kualitatif deskriptif, sehingga penelitian ini menggunakan dua sumber data, yaitu data primer dan data sekunder. Data primer diperoleh langsung dari studi lapangan di mana proses pengumpulan informasi, data, dan fakta secara langsung pada objek penelitian dengan cara: observasi dan wawancara. Data sekunder diperoleh melalui studi literatur atau studi kepustakaan, yaitu dengan mempelajari buku-buku atau bahan-bahan tertulis yang ada hubungannya dengan topik yang akan diteliti, termasuk data-data tertulis lainnya, yang berasal dari lembaga yang dijadikan objek penelitian, termasuk dokumendokumen yang berhubungan dengan penelitian.

\section{Analisis Data}

Data kualitatif adalah data yang berasal dari kehidupan sosial, yang berbentuk foto, tulisan kata, ungkapan kata, deskripsi simbolik, representasi orang, tindakan, dan kejadian-kejadian dalam kehidupan manusia (Neuman, 2007). Analisis data, menurut Patton (1980) dalam Moleong (2009), adalah proses mengatur urutan data, mengorganisasikannya ke dalam suatu pola, kategori dan satuan uraian dasar. Analisis data kualitatif dilakukan sejak tahap awal penelitian, selama pengambilan data sampai dengan akhir terkumpulnya semua data sesuai dengan masalah penelitian.

Teknik analisis data yang digunakan dalam penelitian ini adalah teknik deskriptif-analitik. Menurut Soegiyono (2009), metode atau teknik analisis data deksriptif-analitik merupakan metode penelitian yang bertujuan mendeskripsikan atau memberi gambaran terhadap suatu obyek penelitian yang diteliti melalui sampel atau data yang telah terkumpul dan membuat kesimpulan yang berlaku umum.

Selain data kualitatif yang diolah dengan tahapan tersebut di atas, dilakukan juga pengolahan data kuantitatif, yaitu statistik uji-t. Analisis dengan Statistika uji-t dilakukan menurut petunjuk Walpole (1995), sebagai berikut:

$$
\begin{aligned}
& t=\frac{\left(\bar{X}_{1}-\bar{X}_{2}\right)-\left(\mu_{1}-\mu_{2}\right)}{S p \sqrt{\left(\frac{1}{n_{1}}+\frac{1}{n_{2}}\right)} \text {, asumsi } \mu_{1}=\mu_{2}} \\
& S p^{2}=\frac{\left(n_{1}-1\right) S_{1}^{2}-\left(n_{2}-1\right) S_{2}^{2}}{n_{1}+n_{2}-2} \\
& \mathrm{db}=\mathrm{n}_{1}+\mathrm{n}_{2}-2 \text { pada taraf nyata } \alpha=5 \% .
\end{aligned}
$$

Uji perbandingan dilakukan untuk menentukan signifikansi antara pendapatan rata-rata nelayan dari usaha penangkapan ikan dan pendapatan dari diversifikasi usaha. Guna mempermudah analisis data, maka digunakan aplikasi Microsoft Excel 2007, pada Add-Ins Menu AnalysisToolPak - VBA, yaitu pada menu Data Data Analysis - t-Test: Two Sample Assuming Equal Variances. 
Penentuan signifikansi menggunakan ouput nilai p, yaitu:

- Jika $\mathrm{p}>$ taraf nyata $\alpha=5 \%(0,05)$, maka tidak berbeda nyata;

- Jika $\mathrm{p}<$ taraf nyata $\alpha=5 \%(0,05)$, maka berbeda nyata.

\section{HASIL DAN PEMBAHASAN}

\section{Alokasi Sumber daya Masyarakat}

Usaha perikanan tangkap di Desa Uso telah dilaksanakan secara turun menurun. Kegiatan perikanan tangkap dilakukan oleh masyarakat, baik secara berkelompok maupun mandiri. Pilihan melaut dalam mendapatkan ikan dilakukan secara berkelompok terkait kebutuhan alat tangkap jaring yang dalam pengoperasiannya harus membagi tugas dan fungsi. Sedangkan secara mandiri dapat dilakukan pada alat tangkap pancing ulur karena tidak membutuhkan pembagian tugas dan fungsi.

Usaha perikanan tangkap sendiri merupakan usaha yang membutuhkan keterkaitan antar komponen tertentu agar hasil yang diperoleh dapat maksimal. Jika satu atau beberapa komponen yang menjadi syarat dalam usaha perikanan tangkap tidak dipenuhi, maka produksi yang dihasilkan tidak akan maksimal. Kesteven (1973) mengemukakan, bahwa komponen-komponen yang berperan dalam sistem perikanan tangkap, yaitu masyarakat, sarana produksi, proses produksi, prasarana pelabuhan, sumberdaya ikan, pengolahan, pemasaran, dan aspek legal. Komponen-komponen ini bersinergi satu dengan lainnya membentuk sistem usaha penangkapan ikan.

Komponen-komponen yang harus ada, menurut Kesteven (1973), dalam memaksimalkan usaha perikanan tangkap, kondisi yang ada di Desa Uso, secara eksplisit, sulit untuk dipenuhi bagi masyarakat pesisir yang berprofesi sebagai nelayan. Profesi nelayan, umumnya, didominasi oleh nelayan sambilan yang melaut secara tradisional dan sangat tergantung pada kondisi alam, serta hanya memiliki peralatan tangkap yang tergolong sederhana.

Gambar 1 memperlihatkan, kepemilikan perahu dayung mempunyai persentase paling sedikit, yaitu sebanyak $12 \%$; demikian pula halnya perahu katinting sebanyak $12 \%$. Selanjutnya, diikuti oleh perahu mesin $20 \mathrm{PK}(32 \%)$ dan perahu mesin 5 PK (40\%). Walaupun terlihat nelayan Desa Uso sudah modern karena sebagian besar perahu yang dimiliki sudah menggunakan mesin, namun kepemilikan perahu bermesin, terutama perahu bermesin 20 PK merupakan perahu yang disumbangkan oleh perusahaan dan atau PEMDA untuk kelompok nelayan.

Operasi penangkapan ikan untuk nelayan dalam kelompok harus bergilir. Hal ini dilakukan, karena jumlah anggota kelompok sebanyak 10-15 orang, sedangkan perahu bermesin $20 \mathrm{PK}$ hanya mampu mengangkut 5-10 orang untuk satu trip operasi penangkapan ikan. Kendala inilah menyebabkan maksimalisasi usaha penangkapan ikan tidak dapat tercapai. Ditambah lagi, harus membagi hasil kepada sesama anggota kelompok yang turun melaut.

Pada perahu bermesin $5 \mathrm{PK}$, katinting dan perahu dayung memiliki kendala dalam hal fishing ground; fishing ground yang jauh bukan tidak mampu ditempuh oleh perahu mesin $5 \mathrm{PK}$, namun keterbatasan ruang perahu yang menyebabkan nelayan tidak dapat menyediakan es di mana membutuhkan ruang cukup besar jika harus mencari ikan pada jarak yang jauh. Ketidakmampuan perahu

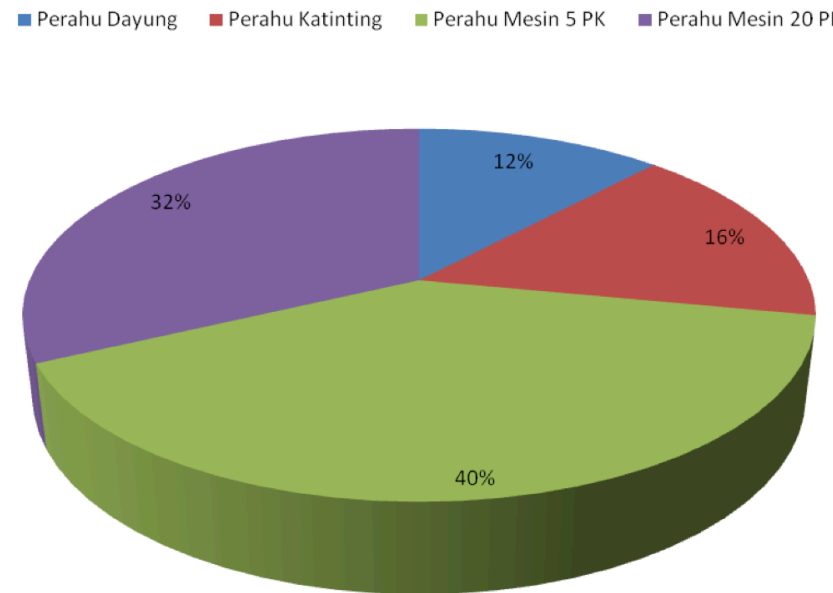

Gambar 1. Kepemilikan Perahu pada Nelayan di Desa Uso, Kecamatan Batui, Kabupaten Banggai, Sulawesi Tengah 
nelayan membawa es berkonsekuensi pada ketahanan ikan dalam perjalanan pulang. Jarak fishing ground yang jauh membutuhkan waktu tempuh yang lama, apalagi jika hanya menggunakan katinting atau perahu dayung. Kondisi ini menyebabkan ikan akan mengalami proses kerusakan sehingga akan dengan mudah ditolak di pasaran.

Kombinasi berbagai keterbatasan pada nelayan di Desa Uso, dengan sendirinya memperlemah posisi tawar nelayan, yang diakibatkan oleh hasil tangkapan kurang. Hal ini dipertegas oleh Siswanto (2008), bahwa nelayan identik dengan keterbatasan aset, lemahnya kemampuan modal, posisi tawar dan akses pasar. Demikian pula asset yang dimiliki nelayan tidak bisa dialihfungsikan, hal mana kapal dan alat penangkapan ikan sulit untuk diubah bentuk dan fungsinya untuk digunakan bagi kepentingan lain (Smith, 1983).

Nelayan Desa Uso, pada akhirnya, dengan kondisi alat tangkap dan sarana transportasi yang ada, hanya mampu subsisten, yaitu hasil dari usaha penangkapan ikan hanya untuk memenuhi kebutuhan sehari-hari. Kondisi demikian memaksa nelayan menjalani kehidupan hari demi hari dalam keterbatasan, jika hanya menggantungkan kehidupan pada usaha penangkapan ikan.

\section{Matapencaharian di Luar Usaha Perikanan}

Dalam memenuhi kebutuhan hidup, nelayan Desa Uso, tidak sepenuhnya menggantungkan penghasilan mereka dengan usaha penangkapan ikan. Sumber mata pencaharian lain yang dapat dilakukan oleh nelayan, yaitu buruh bangunan, buruh perusahaan, bertani, pedagang, dan ojek. Pada semua jenis pekerjaan yang dapat dilakukan di luar usaha penangkapan ikan, sebagian besar mereka memilih menjadi buruh perusahaan $(32 \%)$, pedagang (24\%), bertani (20\%), ojek, dan buruh bangunan $(12 \%)$. Pilihan bekerja sebagai buruh perusahaan paling banyak dilakukan karena serapan tenaga kerja paling banyak dari perusahaan (PT. Dongi Senoro LNG). Pekerjaan yang ditawarkan oleh perusahaan, yaitu sekuriti, cleaning service, office boy, dan kuli perusahaan.

Pilihan sebagai pedagang dilakukan nelayan yang mempunyai penghasilan yang cukup baik. Biasanya, nelayan berdagang dengan menginvestasikan penghasilan dari usaha penangkapan ikan, maupun dari uang pinjaman sebagai modal usaha berdagang. Kios, warung, dan ruko merupakan investasi yang dilakukan nelayan guna menjalankan usaha dagang mereka. Usaha perdagangan bahan pokok merupakan pilihan yang paling banyak dilakukan; karena perputaran barang cepat, maka berdampak pada cepatnya pengembalian modal dan tingkat keuntungan.

Kegiatan bertani merupakan kegiatan yang dilakukan oleh nelayan Desa Uso sebagai pengisi waktu luang jika kondisi cuaca tidak baik untuk melakukan usaha penangkapan ikan. Bertani merupakan kegiatan turun-temurun, karena lahan garapan merupakan warisan dari orang tua. Pada nelayan yang mempunyai lahan pertanian, kegiatan bertani dilakukan secara rutin. Membersihkan, menanam, merawat tanaman, pemanen, dan penjualan dilakukan di sela-sela kegiatan usaha penangkapan ikan. Dengan demikian, baik usaha pertanian maupun usaha penangkapan ikan dilakukan sekaligus sepanjang tahun.

Pada nelayan yang tidak mempunyai lahan pertanian, kegiatan bertani dilakukan sebagai buruh tani. Buruh tani diperlukan pada semua kegiatan bertani yang disebutkan sebelumnya. Pada musimmusim penangkapan yang tidak baik, disebabkan oleh faktor cuaca dan musim ikan, nelayan mengalihkan pekerjaannya sebagai buruh tani, mengerjakan pekerjaan sebagai pembersih kebun, perawat tanaman dan proses panen sampai pada penjualan hasil panen produk pertanian.

Buruh bangunan merupakan pilihan pekerjaan membantu nelayan Desa Uso dalam memenuhi kebutuhan hidup. Pada musim jelek, nelayan sambil menunggu cuaca bersahabat dan atau musim ikan tiba, waktu lowong yang ada diisi dengan mengambil pekerjaan sebagai buruh bangunan. Buruh bangunan tidak memerlukan keahlian khusus dalam menjalankan aktivitas pembangunan. Buruh bangunan memerlukan tenaga dari nelayan untuk mengangkut bahan bangunan, mencampur kombinasi semen, pasir, kerikil, dan lain-lain dalam pengerjaan proyek pembangunan, misalnya rumah, toko, bangunan perusahaan, bangunan pemerintah, jalan, jembatan, dermaga dan lain-lain. Dengan penghasilan rata-rata Rp. 100.000 per hari sebagai buruh bangunan, nelayan rela mengganti sementara pekerjaan mencari ikan untuk menambah penghasil dan mengisi waktu lowong karena usaha penangkapan yang terganggu faktor cuaca dan musim ikan. 
Tabel 1. Rata-rata Lama Waktu (tahun) dan Pendapatan (Rp.) dari Diversifikasi Usaha di Luar Usaha Penangkapan Ikan pada Nelayan Desa Uso, Kecamatan Batui, Kabupaten Banggai, Sulawesi Tengah

\begin{tabular}{lcc}
\hline \multicolumn{1}{c}{ Diversivikasi Usaha } & Lama Waktu (thn) & Pendapatan (Juta Rp.) \\
\hline Buruh bangunan & 16,00 & 2,50 \\
Buruh perusahaan & 2,13 & 3,75 \\
Ojek & 7,33 & 3,75 \\
Pedagang & 1,00 & 5,00 \\
Bertani & 26,00 & 3,50 \\
Rata-rata & 10,49 & 3,70 \\
\hline
\end{tabular}

Pada nelayan Desa yang mempunyai keterampilan membawa kendaraan roda dua (motor), pilihan pekerjaan di luar usaha penangkapan ikan yang dapat dilakukan, yaitu sebagai tukang ojek. Potensi penghasilan cukup besar sebagai tukang ojek. Hal ini disebabkan oleh kesenjangan sarana transportasi di mana pada daerah-daerah tertentu kendaraan umum tidak melayani rute tersebut. Hal ini merupakan potensi sebagai penghasilan yang bisa diraih. Sewa ojek Rp. 10.000 - 20.000 per lokasi, tergantung jarak tempuh merupakan potensi penghasilan yang cukup baik. Masih sedikitnya nelayan yang melakukan pekerjaan sampingan sebagai tukang ojek, karena terkendala modal untuk membeli motor dan belum mempunyai keterampilan dan atau surat izin mengemudi motor.

\section{Diversifikasi Usaha dan Kesejahteraan Nelayan}

Tabel 1 menunjukkan kegiatan yang dilakukan oleh nelayan Desa Uso, yang merupakan rutinitas sehari-hari dan bertujuan untuk menambah pendapatan. Hal ini menggambarkan, bahwa nelayan di desa ini telah melaksanakan diversifikasi usaha sejak 26 tahun yang lalu, yaitu kegiatan diversivikasi usaha kegiatan bertani. Kegiatan sebagai buruh bangunan menempati urutan kedua dengan diversivikasi selama 16 tahun, diikuti oleh tukang ojek sejak 7 tahun yang lalu, buruh perusahaan sejak 2 tahun lalu, dan pedagang dilakukan terkini, yaitu 1 tahun yang lalu.

Lama waktu melakukan diversifikasi, pada dasarnya, menggambarkan usaha yang dilakukan selama ini dapat membantu dalam peningkatan penghasilan atau dapat mengganti kehilangan waktu melaut. Kehilangan waktu melaut berpotensi terhadap kehilangan penghasilan, yang disebabkan tidak adanya ikan sebagai barang yang dapat dijual

\section{Analisis Keseluruhan Rata-rata Pendapatan Nelayan dan Diversifikasi}

Pendapatan rata-rata yang dihasilkan dari usaha penangkapan ikan dan dari diversifikasi usaha merupakan perbandingan yang dianalisis guna menggambarkan perbandingan potensi pendapatan. Table 2 menampilkan hasil uji-t di mana menunjukkan tidak ada perbedaan antara rata-rata pendapatan per bulan dari usaha nelayan dan ratarata pendapatan dari diversifikasi usaha $(p>0,05)$. Rata-rata pendapatan yang mampu dihasilkan oleh nelayan dari diversifikasi usaha lebih tinggi dari pada usaha di bidang penangkapan ikan; namun secara Statistika, hal ini tidak menunjukkan perbedaan nyata, baik pendapatan yang dihasilkan dari usaha penangkapan ikan maupun pendapatan yang dihasilkan dari diversifikasi usaha di berbagai bidang.

Hasil ini mengindikasikan, bahwa secara umum usaha meningkatkan pendapatan dari nelayan di Desa Uso hannyalah sebagai pengganti pendapatan yang hilang karena tidak melaut oleh karena keadaan cuaca dan atau musim ikan. Diversifikasi usaha dari nelayan pada umumnya dilakukan pada saat tidak melaut; namun beberapa diversifikasi usaha dilakukan secara bersamaan, yaitu pada musim ikan dilakukan pada jeda waktu sebelum melaut berikutnya. Pada jeda waktu atau saat istirahat inilah nelayan melakukan kegiatan-

Table 2. Pendapatan rata-rata Nelayan Desa Uso, Kecamatan Batui, Kabupaten Banggai, Sulawesi Tengah

\begin{tabular}{ccc}
\hline & Usaha Nelayan & Usaha Diversifikasi \\
\hline $\begin{array}{l}\text { Pendapatan rata-rata } \\
\text { (juta Rp. per bulan) }\end{array}$ & 3,28 & 3,85 \\
\hline \multicolumn{1}{c}{ Significant } & $\mathrm{P}(\mathrm{T}<=\mathrm{t})$ two-tail $=0,13$ \\
$(\mathrm{p}>0,05)$
\end{tabular}


Srinurmaningsi et al.: Diversification of business and its implications for the welfare of traditional fishermen...

Tabel 3. Uji-t perbandingan rata-rata pendapatan usaha penangkapan ikan dan rata-rata pendapatan dari berbagai diversifikasi usaha pada nelayan Desa Uso, Kecamatan Batui, Kabupaten Banggai, Sulawesi Tengah

\begin{tabular}{|c|c|c|c|c|c|c|}
\hline & $\begin{array}{c}\text { Penangkapan } \\
\text { Ikan }\end{array}$ & $\begin{array}{c}\text { Buruh } \\
\text { Bangunan }\end{array}$ & $\begin{array}{c}\text { Buruh } \\
\text { Perusahaan }\end{array}$ & Ojek & Pedagang & Tani \\
\hline $\begin{array}{l}\text { Pendapatan (juta Rp. per } \\
\text { bulan) }\end{array}$ & 3,28 & $2,50 * *$ & $3,75^{\mathrm{ns}}$ & $3,75^{\mathrm{ns}}$ & $5,00 * *$ & $3,50^{\mathrm{ns}}$ \\
\hline $\begin{array}{c}\text { Signifikansi } \\
\mathrm{P}(\mathrm{T}<=\mathrm{t}) \text { two-tail }\end{array}$ & & $\begin{array}{c}0,006 \\
(p<0,05)\end{array}$ & $\begin{array}{c}0,35 \\
(p>0,05)\end{array}$ & $\begin{array}{c}0,08 \\
(p>0,05)\end{array}$ & $\begin{array}{l}7,2 \mathrm{E}-07 \\
(p<0,05)\end{array}$ & $\begin{array}{c}0,83 \\
(p>0,05)\end{array}$ \\
\hline
\end{tabular}

kegiatan diversifikasi, misalnya mengontrol tanaman pada usaha pertanian, menjaga warung atau kios, dan menjadi tukang ojek. Sedangkan kegiatan diversifikasi yang tidak dapat dilakukan pada waktu jeda atau istirahat, yaitu sebagai buruh bangunan dan atau buruh perusahaan.

Jenis pekerjaan sebagai buruh bangunan dan buruh pabrik tidak dapat dilakukan pada waktu jeda atau waktu istirahat nelayan sebelum trip berikutnya. Hal ini disebabkan karena kedua jenis pekerjaan tersebut memerlukan waktu dan tenaga ekstra. Karakteristik khusus yang dibutuhkan, yaitu waktu dan tenaga ekstra inilah menyebabkan kedua kegiatan ini hanya dapat dilakukan pada saat cuaca jelek atau tidak musim ikan. Pada kondisi cuaca jelek atau tidak musim ikan, nelayan mempunyai waktu luang dan tenaga ekstra untuk memenuhi tuntutan pekerjaan sebagai buruh bangunan dan buruh perusahaan.

\section{Analisis Parsial Rata-rata Pendapatan Nelayan dan Diversifikasi}

Table 3 menunjukkan hasil uji-t di mana perbedaan sangat nyata pada diversifikasi usaha nelayan Desa Uso, yaitu sebagai buruh bangunan dan pedagang. Diversifikasi usaha sebagai buruh bangunan menghasilkan pendapatan yang signifikan lebih rendah dibanding usaha penangkapan ikan; sedangkan diversifikasi usaha sebagai pedagang menghasilkan pendapatan signifikan lebih tinggi.

Hasil tidak signifikan terindentifikasi pada diversifikasi usaha sebagai buruh perusahaan, tukang ojek, dan bertani. Hasil ini mengindikasikan usaha penangkapan ikan dan diversifikasi usaha sebagai buruh perusahaan, tukang ojek, dan bertani menghasilkan pendapatan yang tidak berbeda dengan usaha penangkapan ikan.

Prinsip diversifikasi dalam dunia perikanan tidak jauh berbeda dengan diversifikasi pada usaha tani di mana diversifikasi dalam dunia perikanan merupakan pilihan ragam usaha di luar usaha penangkapan ikan, yang bertujuan untuk meningkatkan pendapatan dengan memanfaatkan potensi sumber daya yang ada. Nelayan di Desa
Uso mempunyai keterbatasan pada usaha penangkapan ikan yang terkendala pada faktor cuaca dan musim ikan. Menurut Yuliati et al., (2003), khusus pada usaha tani, alasan yang menjadi penyebab petani bekerja di luar usaha tani adalah tidak cukupnya pekerjaan dan pendapatan dari usaha tani, sifat pendapatan dari usaha tani (tanaman pangan) yang musiman, banyak risiko, dan ketidakpastian dalam berusaha tani juga merupakan penyebab yang dominan.

Ketidakpastian dalam usaha penangkapan ikan merupakan kondisi di luar kontrol nelayan. Cuaca yang sering berubah-ubah sering memaksa nelayan untuk tinggal di rumah. Pada cuaca yang baik, namun jika tidak pada musim ikan, nelayan juga diperhadapkan dengan risiko dan ketidakpastian untuk pergi melaut atau tidak. Pertaruhan opportunity cost demikian besar, yaitu jika melaut dan tidak mendapatkan ikan akan mengalami kerugian tenaga dan biaya. Jika tidak melaut dan kemungkinan mendapatkan ikan, walaupun bukan musim ikan, maka potensi keuntungan tidak dapat diraih.

Rasionalisasi diversifikasi menjadi pilihan yang harus bijaksana untuk memanfaatkan waktu, tenaga, dan dana. Sependapat dengan itu, Kusnadi (2002) mengatakan, bahwa keputusan untuk melakukan diversifikasi pekerjaan merupakan upaya dan pilihan rasional yang akan lebih menguntungkan kepentingan rumah tangga nelayan dalam menjamin kelangsungan hidup dan meningkatkan kualitas kehidupannya. Melakukan diversifikasi pekerjaan akan semakin memberi keleluasaan dan kebebasan kepada nelayan untuk memperoleh penghasilan dari beragam sumber dan peluang kerja; dalam konteks diversifikasi tersebut, kegiatan kenelayanan tetap dijadikan sebagai salah satu sumber pendapatan yang bisa dimanfaatkan pada saat yang tepat.

Pilihan model diversifikasi hendaknya mempertimbangkan aspek regional sehingga model yang akan diterapkan di suatu daerah hendaknya cocok dengan potensi dan daya dukung dari sumber daya alam yang tersedia. Pengembangan model 
Tabel 4. Rata-rata cash-flow dan kelayakan finansial kegiatan penangkapan ikan nelayan Desa Uso, Kecamatan Batui, Kabupaten Banggai, Sulawesi Tengah

\begin{tabular}{lcccccc}
\hline & Pancing & $\begin{array}{c}\text { Pancing }+ \\
\text { Bubu }\end{array}$ & $\begin{array}{c}\text { Pancing }+ \\
\text { Jaring }\end{array}$ & Jaring & $\begin{array}{c}\text { Jaring }+ \\
\text { Bubu }\end{array}$ & $\begin{array}{c}\text { Pancing }+ \\
\text { Jaring }+ \text { Bubu }\end{array}$ \\
\hline Total Cost & 21,35 & 22,20 & 22,15 & 24,65 & 25,50 & 27,25 \\
Total Pendapatan per & 38,70 & 42,75 & 23,85 & 39,42 & 56,25 & 38,79 \\
$\begin{array}{l}\text { Tahun (jutaRp.) } \\
\text { LabaBersih per Tahun }\end{array}$ & 17,35 & 20,55 & 1,70 & 14,77 & 30,75 & 11,54 \\
(jutaRp.) & 1,81 & 1,93 & 1,08 & 1,60 & 2,21 & 1,42 \\
BC RATIO & 94,88 & 122,40 & 76,34 & 140,13 & 223,04 & 131,49 \\
BEP-unit & 2,37 & 3,06 & 1,91 & 3,50 & 5,58 & 3,29 \\
BEP-penjualan & 1,44 & 1,46 & 20,59 & 3,72 & 1,95 & 5,63 \\
ROI & & & & & & \\
\hline
\end{tabular}

Tabel 5. Rata-rata Cash-flow dan kelayakan finansial kegiatan diversifikasi Usaha nelayan Desa Uso, Kecamatan Batui, Kabupaten Banggai, Sulawesi Tengah

\begin{tabular}{lrrrrr}
\hline & $\begin{array}{c}\text { Buruh } \\
\text { Bangunan }\end{array}$ & Buruh Pabrik & $\begin{array}{c}\text { Tukang } \\
\text { Ojek }\end{array}$ & Pedagang & Petani \\
\hline Total Cost & 5,00 & 5,00 & 8,40 & 37,45 & 5,00 \\
Total Pendapatan per Tahun (juta Rp.) & 12,50 & 18,75 & 26,25 & 60,00 & 14,00 \\
Laba Bersih per Tahun (juta Rp.) & 7,50 & 13,75 & 17,85 & 22,55 & 9,00 \\
BC RATIO & 2,50 & 3,75 & 3,13 & 1,60 & 2,80 \\
BEP-unit & 12,51 & 14,01 & 59,45 & 155,13 & 12,99 \\
BEP-penjualan & 1,25 & 1,40 & 4,46 & 15,51 & 1,30 \\
ROI & 1,33 & 0,73 & 1,68 & 5,54 & 1,11 \\
\hline
\end{tabular}

diversifikasi pada wilayah pesisir juga penting memperhatikan aspek regional sehingga penekanan diversifikasi dititik beratkan pada upaya memanfaatkan potensi wilayah pesisir berdasarkan daya dukung wilayah pesisir yang ada dengan memperhatikan aspek sosio-kultur masyarakat setempat (Anna, 2006).

Diversifikasi usaha nelayan Desa Uso, pada berbagai tipe pekerjaan, memiliki implikasi berbeda, baik dalam meningkatkan pendapatan keluarga, pengganti pendapatan yang hilang karena tidak melaut, maupun pengisi waktu lowong. Alokasi waktu, tenaga, dan dana merupakan kombinasi sumber daya nelayan dalam menentukan bentuk diversifikasi usaha di luar usaha penangkapan ikan.

Usaha perikanan tangkap yang terikat pada kekuatan aset perikanan (fixity and rigidity of fishing assets) dapat menjadi penyebab utama nelayan tetap terperangkap dalam kemiskinan (Smith, 1983) di mana kapal dan alat penangkapan ikan sulit untuk diubah bentuk dan fungsinya untuk digunakan bagi kepentingan lain. Akibatnya, pada saat produktifitas rendah, nelayan tidak mampu untuk mengalihfungsikan atau melikuidasi aset tersebut. Kondisi ini menggambarkan, bahwa nelayan tradisional tidak mungkin dapat bertahan hidup hanya dengan menggantungkan sumber pendapatan hanya dari kegiatan penangkapan ikan. Kendala cuaca, musim ikan, armada penangkapan, dan alat tangkap sederhana tidak mampu menutup kebutuhan nelayan pada saat tidak melaut. Pendapatan selama melaut di musim baik tidak cukup untuk dijadikan cadangan pada musim jelek.

\section{Cash-flow Usaha Nelayan dan Diversifikasi}

Tingkat pendapatan usaha nelayan di Desa Uso ditentukan berdasarkan jenis alat tangkap. Jenis alat tangkap dapat merepresentasikan investasi, biaya tetap, biaya tidak tetap, produksi, dan harga.

Table 4 menampilkan cash-flow dan analisis finansial di Desa Uso di mana menunjukkan, bahwa usaha nelayan layak dilaksanakan dengan melihat kriteria nilai BC-Ratio lebih dari satu pada tingkat pengembalian investasi yang berbeda-beda. Table 5 menunjukkan diversifikasi usaha nelayan Desa Uso layak dilaksanakan dengan melihat kriteria nilai BC-Ratio lebih dari satu pada tingkat pengembalian investasi yang berbeda-beda. 
Srinurmaningsi et al.: Diversification of business and its implications for the welfare of traditional fishermen...

\section{KESIMPULAN}

Beberapa hal dapat disimpulkan dari penelitian ini, yaitu:

1. Terdapat perbedaan yang signifikan antara usaha penangkapan ikan dan diversifikasi usaha di Desa Uso di mana sebagai buruh bangunan memiliki pendapatan lebih rendah, dan sebagai pedagang lebih tinggi. Sedangkan diversifikasi usaha sebagai buruh perusahaan, tukang ojek, dan bertani, tidak berbeda terhadap pendapatan.

2. Diversifikasi usaha nelayan berimplikasi positif pada kehidupan nelayan dalam memanfaatkan waktu luang tidak melaut karena faktor cuaca, mengganti kehilangan pendapatan karena tidak melaut, dan mengkombinasikan berbagai usaha di luar usaha penangkapan ikan yang berpotensi pada peningkatan pendapatan keluarga nelayan di Desa Uso.

3. Cash-flow dan analisis finansial menunjukkan usaha perikanan tangkap layak dilaksanakan; demikian pula diversifikasi usaha layak dilaksanakan sebagai penunjang usaha nelayan di Desa Uso.

Ucapan terima kasih. Penelitian ini terlaksana berkat dukungan dari aparat dan masyarakat nelayan Desa Uso, Kecamatan batui, Kabupaten Banggai, Provinsi Sulawesi Tengah. Untuk dukungan pengambilan data lapangan, pada mereka semua di ucapkan terima kasih.

\section{REFERENSI}

ANDAKI, J.A. (2012) Masyarakat Pantai Kota Manado Pasca Reklamasi. Disertasi. Bandung: Program Pascasarjana Universitas Padjadjaran.
ANNA, S. (2006) Analisis Ekonomi Kawasan Konservasi Laut: Optimalisasi dan Dampak Sosial Ekonomi Pada Perikanan. Jurnal Kebijakan dan Riset Sosial Ekonomi Kelautan dan Perikanan. Badan Riset Kelautan dan Perikanan. Jakarta: Departemen Kelautan dan Perikanan.

CRESWELL, J.W. (2009) Research Design: Qualitative, Quantitative, and Mixed Methods Approach. Sage Pubications.

KUSNADI, M.A. (2002) Konflik Sosial Nelayan, Kemiskinan dan Perebutan Sumber Daya Perikanan. Yogyakarta: LkiS.

MOLEONG, L.J. (2009) Metodologi Penelitian Kualitatif. Edisi Revisi. Cetakan Keduapuluh Enam. Bandung: Penerbit PT. Remaja Rosdakarya.

NEUMAN, W.L. (2007) Basic ofSocialResearch. Qualitative and Quantitative Approaches. Second Edition. Boston: Pearson Education, Inc. USA.

SISWANTO B. (2008) Kemiskinan dan Perlawanan Kaum nelayan. Malang: Laks-bang Mediatama. Hal 193-216.

SMITH I.R. (1983) A Research Framework for Traditional Fisheries. Manila: International Center for Living Aquatic Resources Management (ICLARM), Manila Studies and Reviews.

SMITH, I.R. (1987) Peningkatan pendapatan Perikanan pada Sumberdaya yang sudah Lebih Tangkap (Bahasa Indonesia) dalam Marahuddin dan Smith (editors). Ekonomi Perikanan. Jakarta: Yayasan Obor-Gramedia.

Received: 25 June 2017 Accepted: 10 August 2017 